\title{
CHEMICAL COMPOSITION AND ANTIOXIDANT ACTIVITY OF FICUS ELASTICA ROXB. EX HORNEM AND RAPHANUS SATIVUS L. SELECTIVE DRY EXTRACTS WITH POTENTIAL ANTIDIABETIC ACTIVITY
}

\author{
AL HILFI ZAID ABDULRIDHA FLAYYH ${ }^{1 \#}$, IOANA NENCU ${ }^{2 *}$, TEODORA COSTEA ${ }^{2 \#,}$ \\ CERASELA ELENA GÎRD ${ }^{2}$, CRISTINA SILVIA STOICESCU ${ }^{3 *}$, ADRIANA IULIANA ANGHEL ${ }^{3 *}$, \\ ROBERT VIOREL ANCUCEANU ${ }^{3 *}$, MIHAELA DINU ${ }^{3}$, FLORIANA ELVIRA IONICA ${ }^{4}$, OANA \\ CRISTINA ŞEREMET ${ }^{1}$, SIMONA NEGREŞ ${ }^{1}$
}

\author{
${ }^{I}$ Pharmacology and Clinical Pharmacy Department, Faculty of Pharmacy, "Carol Davila" University of Medicine and \\ Pharmacy, 6 Traian Vuia Street, 020956, Bucharest, Romania \\ ${ }^{2}$ Pharmacognosy, Phytochemistry, Phytotherapy Department, Faculty of Pharmacy, "Carol Davila” University of Medicine \\ and Pharmacy, 6 Traian Vuia Street, 020956, Bucharest, Romania \\ ${ }^{3}$ Pharmaceutical Botany Department, Faculty of Pharmacy, "Carol Davila” University of Medicine and Pharmacy, 6 Traian \\ Vuia Street, 020956, Bucharest, Romania \\ ${ }^{4}$ Faculty of Pharmacy, University of Medicine and Pharmacy of Craiova, Craiova, Romania
}

*corresponding author: ioanaitudor@gmail.com

${ }^{\#}$ Authors with equal contribution

Manuscript received: May 2019

\begin{abstract}
The aim of our study consisted in obtaining, phytochemical and antioxidant activity evaluation of two selective dry extracts from the leaves of Ficus elastica Roxb. ex Hornem and Raphanus sativus L., with potential use in metabolic diseases. The results of the phytochemical assessment of the two hydroethanolic dry extracts (the employed hydroethanolic mixture were: $70 \%$ ethanol (v/v) for Fici elastici folium and 50\% ethanol (v/v) for Raphani sativi folium) indicated the following: Fici elastici extractum (FEE) - 3.6140 $\pm 0.4000 \mathrm{~g} \%$ flavonoids expressed as hyperoside, $5.950 \pm 0.3800 \mathrm{~g} \%$ phenolcarboxylic acids expressed as chlorogenic acid, $13.3299 \pm 0.1583 \mathrm{~g} \%$ total phenolic compounds expressed as tannic acid; 2. Raphani sativi extractum (RSE) - $6.7300 \pm 0.6600 \mathrm{~g} \%$ flavonoid expressed as hyperoside, $3.1263 \pm 0.1500 \mathrm{~g} \%$ phenolcarboxylic acids expressed as chlorogenic acid, $21.4175 \pm 0.9454 \mathrm{~g} \%$ total phenolic compounds expressed as tannic acid. The HPLC analysis confirmed the presence of apigenin-7-glucoside in Raphani sativi extractum. Evaluation of the antiradicalar activity of the dry extracts was determined by scavenger activity of free radicals, 2,2-diphenyl-1-picrylhydrazyl (DPPH), 2,2'-azinobis-(3-ethylbenzothiazoline-6-sulfonic acid) (ABTS $\bullet$ ) and by ferric reducing power method. The antioxidant activity was expressed as EC50 mg $/ \mathrm{mL}$. The following results were obtained: EC50 $0_{\mathrm{DPPH}}=6.4166 \pm 0.3329 \mathrm{mg} / \mathrm{mL}, \mathrm{EC} 50_{\mathrm{ABTS}}=0.0768 \pm 0.0020 \mathrm{mg} / \mathrm{mL}$, $\mathrm{EC}_{5} 0_{\text {ferric reducing power }}=0.4027 \pm 0.0016 \mathrm{mg} / \mathrm{mL}$ (for $F E E$ ); $\mathrm{EC} 50_{\mathrm{DPPH}}=7.5100 \pm 0.1414 \mathrm{mg} / \mathrm{mL}, \mathrm{EC} 50_{\mathrm{ABTS}}=0.2611 \pm 0.1893$ $\mathrm{mg} / \mathrm{mL}, \mathrm{EC} 50_{\text {ferric reducing power }}=1.3935 \pm 0.0111 \mathrm{mg} / \mathrm{mL}$ (for $R S E$ ).
\end{abstract}

\section{Rezumat}

Scopul lucrării a constat în obţinerea, caracterizarea fitochimică şi evaluarea activităţii antioxidante a două extracte uscate, selective, obţinute din frunzele de Ficus elastica Roxb. ex Hornem şi Raphanus sativus L., cu potenţială activitate în tratamentul afecţiunilor metabolice. Extracte hidroalcoolice uscate (obţinute în etanol 70\% pentru Fici elastici folium şi în etanol 50\% pentru Raphani sativi folium) conţin: Fici elastici extractum (FEE) - 3,6140 $\pm 0,4000$ g\% flavone exprimate în hiperozidă, 5,950 $\pm 0,3800 \mathrm{~g} \%$ acizi fenol-carboxilici exprimaţi în acid clorogenic, 13,3299 $\pm 0,1583 \mathrm{~g} \%$ polifenoli totali exprimaţi în acid tanic; Raphani sativi extractum (RSE) - 6,7300 $\pm 0,6600 \mathrm{~g} \%$ flavone exprimate în hiperozidă, 3,1263 \pm $0,1500 \mathrm{~g} \%$ acizi fenol-carboxilici exprimaţi în acid clorogenic, 21,4175 $\pm 0,9454 \mathrm{~g} \%$ polifenoli totali exprimaţi în acid tanic. Analiza HPLC a evidenţiat prezenţa apigenin-7-glucozidei în RSE. Activitatea antioxidantă a extractelor a fost determinată pe baza capacităţii de scavenger a radicalilor liberi DPPH (2,2-diphenyl-1-picrylhydrazyl), ABTS•+ (acidul 2,2'-azinobis-3etilbenzotiazolin-6-sulfonic) şi pe baza capacităţii de reducere a ferului. Capacitate antioxidantă a fost evaluată pe baza EC50 $(\mu \mathrm{g} / \mathrm{mL})$. S-au obţinut următoarele rezultate: $\mathrm{EC} 50_{\mathrm{DPPH}}=6,4166 \pm 0,3329 \mathrm{mg} / \mathrm{mL}, \mathrm{EC} 50_{\mathrm{ABTS}}=0,0768 \pm 0,0020 \mathrm{mg} / \mathrm{mL}$, $\mathrm{EC}_{5} 0_{\text {reducerea ferului }}=0,4027 \pm 0,0016 \mathrm{mg} / \mathrm{mL}$ (pentru $F E E$ ); $\mathrm{EC}_{50} 0_{\mathrm{DPPH}}=7,5100 \pm 0,1414 \mathrm{mg} / \mathrm{mL}, \mathrm{EC} 50_{\mathrm{ABTS}}=0,2611 \pm 0,1893$ $\mathrm{mg} / \mathrm{mL}, \mathrm{EC} 50_{\text {reducerea ferului }}=1,3935 \pm 0,0111 \mathrm{mg} / \mathrm{mL}$ (pentru $R S E$ ).

Keywords: microscopic exam, polyphenols, apigenin-7-glucoside, antioxidant capacity 


\section{Introduction}

The species of the Ficus genus ( $F$. racemosa, $F$. glomerata, $F$. indica, $F$. carica) exhibit numerous therapeutic effects such as: anti-pyretic, gastroprotective, antiulcer and antidiabetic. The leaves of Ficus elastica are less studied and possess parasiticidal, antioxidant, antiallergic and diuretic properties [20, 40].

Raphanus sativus L. is a cruciferous vegetable that is widely consumed across the globe. Different parts of this species are used for medicinal purposes to treat digestive disorders such as: indigestion, digestive inflammation, diarrhoea and abdominal pain. The radish leaves are reputed to poses anti-cancer activity, anti-inflammatory and antidiabetic effects [2, 29].

Taking into consideration the scientific data, the aim of our work was obtaining, phytochemical characterization and evaluation of the antioxidant capacity of two selective dry extracts from the leaves of Ficus elastica Roxb. ex Hornem and Raphanus sativus L. with potential use in metabolic diseases (diabetes mellitus).

\section{Materials and Methods}

Vegetal samples

Ficus elasica Roxb. ex Hornem and Raphanus sativus L. leaves have been used as material. Herbal products were dried and stored in laboratory conditions. The research was carried out in several steps: 1) verification of herbal products identity based on macroscopic and microscopic characteristics; 2) obtaining and characterization of two selective dry extracts 3 ) determination of extracts antioxidant activity.

The herbal products identity was determined based on macroscopic (morpho-anatomical characteristics) and microscopic (performed on surface preparations and cross/longitudinal sections) assays (Labophot 2 Nikon/ digital Leika DMS 1000 microscope, ob. 4x, 10x, 40x, 100x) [10].

Obtaining and characterization of selective dry extracts. $556 \mathrm{~g}$ Fici elastici folium and $977.32 \mathrm{~g}$ Raphani sativi folium were heated twice on a reflux condenser with $70 \%$ ethanol (for Fici elastici folium) and 50\% ethanol (for Raphani sativi folium) for $60 \mathrm{~min}$. using $1: 10$ herbal product/solvent ratio (for the first extraction) and 1:5 (for the second one). After cooling, the combined filtrates were concentrated using a rotary evaporator and then freeze-dried. The solvent choice and concentration were based on scientific literature data $[19,30,39$, $42,43]$. The extraction yield is expressed as the percentage of the total mass of the dry extract $\left(\mathrm{M}_{\mathrm{ext}}\right.$ without water content) with respect to the mass of the raw material $\left(\mathrm{M}_{\mathrm{pv}}\right)$ loaded onto to the flask for solvent extraction: $\mathrm{Y} \%=\left(\mathrm{M}_{\mathrm{ext}} / \mathrm{M}_{\mathrm{pv}}\right) \times 100$. The obtained dry extracts were encoded as follows: FEE Fici elastici extractum and RSE - Raphani sativi extractum.
Spectrophotometric assays. The flavonoids content (FL) was determined based on the chelating reaction with aluminium chloride [14]. Phenolcarboxylic acids (PAC) were assessed based on formation of oxymes in the presence of sodium nitrite/hydrochloric acid and sodium hydroxide [15]. The total phenolic (TPC) content was evaluated based on the capacity to reduce molybdenic(VI) compounds [36]. For all spectrophotometric determinations a Jasco V-530 spectrophotometer (Jasco, Japan) was used. The following calibration curves were used to calculate the content of active compounds: hyperoside (linearity range: 7.32 - $34.16 \mu \mathrm{g} / \mathrm{mL}, \mathrm{r}=0.9998, \mathrm{n}=12$ ), chlorogenic acid (linearity range: $0.0113-0.0527 \mathrm{mg} / \mathrm{mL}, \mathrm{r}=$ $0.9998, \mathrm{n}=6$ ) and tannic acid (linearity range: 2.0 $12.0 \mu \mathrm{g} / \mathrm{mL}, \mathrm{r}=0.9990, \mathrm{n}=10$ ).

HPLC analysis was carried out using a previously published external standard method with gradient elution and UV detection [15].

Evaluation of the antiradicalar activity of FEE and $R S E$ was determined by means of the following methods: the scavenger activity towards 2,2-diphenyl1-picrylhydrazyl (DPPH) [8,26], 2,2'-azinobis-(3ethylbenzothiazoline-6-sulfonic acid) (ABTS •+) $[9,33]$ free radicals and ferric reducing power [28].

Preparation of samples for antioxidant activity evaluation

For FEE: $0.5000 \mathrm{~g}$ dry extract were dissolved in $25 \mathrm{~mL}$ or $50 \mathrm{~mL}$ of $70 \%$ ethanol (v/v) by ultrasonication. The stock solutions concentration were $1 \%$ (for DPPH assay) and $2 \%$ (for $\mathrm{ABTS}^{\circ+}$ and ferric reducing power assays).

For RSE: $0.5000 \mathrm{~g}$ dry extract were dissolved in $25 \mathrm{~mL}$ of $50 \%$ ethanol $(\mathrm{v} / \mathrm{v})$ by ultrasonication. All antioxidant assays were performed using a $2 \%$ stock solution.

Scavenging activity of free radical DPPH (2,2-diphenyl-1-picrylhydrazyl) $[8,26]$. Briefly, $0.3 \mathrm{~mL}$ of different concentration of analysed extracts (0.8 $10 \mathrm{mg} / \mathrm{mL}$ for $F E E ; 2.5-15 \mathrm{mg} / \mathrm{mL}$ for $R S E$ ) were mixed with $2.7 \mathrm{~mL}$ of freshly prepared $\mathrm{DPPH}^{\circ}$ ethanolic solution $(120 \mu \mathrm{L}, \mathrm{Abs}=0.68 \pm 0.01)$. After $30 \mathrm{~min}$ of incubation, in the dark at room temperature, the absorbance was measured at $517 \mathrm{~nm}$. Ethanol was used as blank. The concentration of analysed dry extracts that inhibited $50 \%$ of the DPPH free radical $\left(\mathrm{EC}_{50}, \mathrm{mg} / \mathrm{mL}\right)$ was determined graphically from the linear regression curve plotted between percent (\%) of inhibition and dry extracts concentrations $(\mathrm{mg} / \mathrm{mL})$.

Radical scavenging of the extracts were calculated as follows and expressed in terms of EC50 (mg/mL extract that scavenge $50 \%$ of DPPH free radical).

$\%$ Inhibition $=\frac{A b s_{(t=0 \mathrm{~min})}-A b s_{(t=30 \mathrm{~min})}}{A b s_{(t=0 \mathrm{~min})}} * 100$, 
FARMACIA, 2019, Vol. 67, 5

where $\mathrm{Abs}(\mathrm{t}=0 \mathrm{~min})$ - absorbance of $\mathrm{DPPH}$ solution; $\mathrm{Abs}(\mathrm{t}=30 \mathrm{~min})$ - absorbance of DPPH solution with sample, after $30 \mathrm{~min}$.

ABTS $^{\circ+}$ radical cation scavenging assay was performed according to Re $\mathrm{R}$ et al. method [9, 14, 33]. The $\mathrm{ABTS}^{*+}$ radical cation was generated by incubation of ABTS diammonium salt ( $7 \mathrm{mM}$ ) with potassium persulphate $(2.45 \mathrm{mM})$ in the dark, at room temperature for $16 \mathrm{~h}$. The absorbance of the $\mathrm{ABTS}^{\circ+}$ radical solution was equilibrated to a value of $0.700 \pm 0.02$ at $\lambda=734$ $\mathrm{nm}$ after dilution with ethanol. Briefly, FEE and RSE stock solutions were diluted with $70 \%$ ethanol and $50 \%$ ethanol in order to obtain solutions with equivalent concentrations of $0.03-0.16 \mathrm{mg} / \mathrm{mL}$ (for $F E E$ ) and $0.2-1 \mathrm{mg} / \mathrm{mL}$ (for $R S E$ ) (test solutions). $0.5 \mathrm{~mL}$ of the tested solutions were treated with $3 \mathrm{~mL}^{\text {of }} \mathrm{ABTS}^{\cdot+}$ free radical and the mixture was kept in the dark. The absorbance of the free radical cation was measured at $\lambda=734 \mathrm{~nm}$ before $\left(\mathrm{A}_{\text {start }}\right)$ and $6 \mathrm{~min}$. after adding the extractive solutions $\left(\mathrm{A}_{\text {end }}\right)$. Ethanol was used as a blank. The ability to scavenge the $\mathrm{ABTS}^{\circ+}$ free radical was calculated according to the following formula: $\mathrm{ABTS}^{\circ+}$ radical scavenging activity $(\%)=\left(\mathrm{A}_{\text {start }}-\mathrm{A}_{\text {end }}\right) / \mathrm{A}_{\text {start }} \times 100$. The concentration of analysed dry extracts that inhibited $50 \%$ of the $\mathrm{ABTS}^{\circ+}$ free radical $\left(\mathrm{EC}_{50}, \mathrm{mg} / \mathrm{mL}\right)$ was determined graphically from the linear regression curve plotted between percent (\%) of inhibition and dry extracts concentrations $(\mathrm{mg} / \mathrm{mL})$.

Ferric reducing power. The reducing power assay was determined according to Oyaizu M method [28]. Briefly, FEE and RSE stock solutions were diluted with $70 \%$ ethanol and $50 \%$ ethanol in order to obtain solutions with equivalent concentrations of $0.03-1.6$ $\mathrm{mg} / \mathrm{mL}$ (for $F E E$ ) and $0.2-2 \mathrm{mg} / \mathrm{mL}$ (for $R S E$ ) (test solutions). $2.5 \mathrm{~mL}$ of the test solutions were mixed with $2.5 \mathrm{~mL}$ of $0.2 \mathrm{M}$ phosphate buffer ( $\mathrm{pH} 6.6)$ and
$2.5 \mathrm{~mL}$ of $1 \%$ potassium ferricyanide. Samples were kept at $50^{\circ} \mathrm{C}$ in a water bath (Raypa, Spain) for $20 \mathrm{~min}$. After, $2.5 \mathrm{~mL}$ of $10 \%$ trichloroacetic acid was added and the mixture was centrifuged at $2500 \mathrm{rpm}$ for $5 \mathrm{~min}$. (Universal 16 centrifuge). The upper layer $(2.5 \mathrm{~mL})$ was mixed with $2.5 \mathrm{~mL}$ water and $0.5 \mathrm{~mL}$ of a $0.1 \%$ ferric chloride solution. The absorbance was measured at $\lambda=700 \mathrm{~nm}$, after $10 \mathrm{~min}$, against a blank that contained all reagents except for tested solutions. A higher absorbance indicates stronger reducing power. The analysed dry extracts concentration providing 0.5 of absorbance $\left(\mathrm{EC}_{50} \mathrm{mg} / \mathrm{mL}\right)$ was determined graphically from the linear regression curve plotted between absorbance and test solutions concentrations $(\mathrm{mg} / \mathrm{mL})$.

Statistic analysis. For each dry extract, three samples were analysed and all assays were carried out in triplicate $(n=3)$. The results are expressed as mean \pm standard deviation. Standard deviation was determined using Microsoft Office (Excell, 2010).

\section{Results and Discussion}

The macroscopic and microscopic examination confirmed the identity of the raw materials based on the correspondence with the characters described in the scientific literature $[6,25,35,38]$. The analysis of both surface preparations and transverse/longitudinal sections for Fici elastici folium revealed an asymmetric heterogenous structure of the lamina with a bistratified palisade (Figure 1a); the adaxial epidermis shows a thick cuticle (characteristic to xerophytic plants) with moniliforme thickening of cell walls (Figure 1b); the hypodermis is characterized by large cells, some of them contain round or oblong shaped gray cystoliths (Figure 1c).

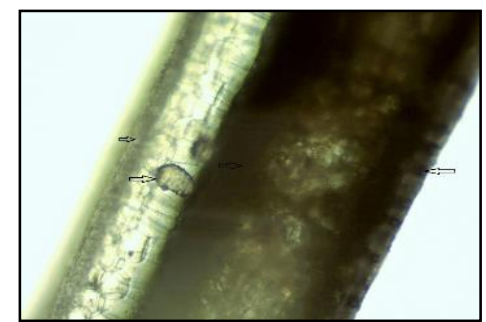

a)

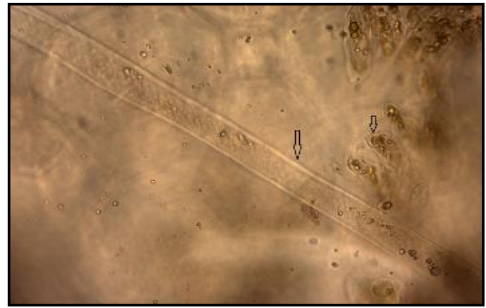

d)

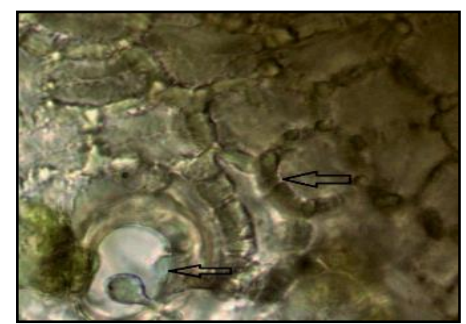

b)

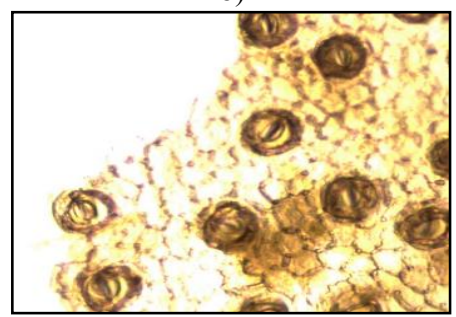

e)

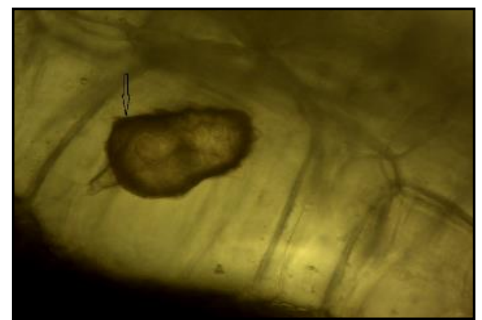

c)

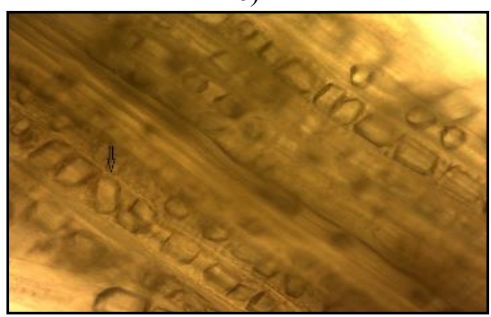

f)

Figure 1.

Anatomical elements for Fici elastici folium: a) asymmetric heterogenous structure of the lamina, ob.40x; b) epidermic cells with moniliforme thickening of cell walls and round cystoliths, ob. 40x; c) cystoliths, ob.100x; d) non-articulated laticifers, ob.4ox; e) anomocitic stomata, ob.10x; f) prismatic crystals, ob.40x 
The midrib has a characteristic shape (a proeminent arch on the abaxial face); subepidermally one can note a mechanic tissue (angular collenchyma) with inegal thick cell walls. Numerous non-articulated laticefers were observed in the parenchyma (Figure 1d). The vascular tissue of the leaves is represented by collateral bundles, which are disposed as an abaxial arch. The abaxial epidermis has numerous stomata submerged in the cuticle (with supra-stomatic chambers) (Figure 1e), due to plant's specific adaptation to environmental conditions. In the surface preparations we have observed numerous prismatic crystals along the veins (Figure 1f). The observed anatomical elements are in agreement with the scientific data $[6,7,16$,
$35,38]$, however the type and shape of the observed cystoliths represent an original aspect of our research. For Raphani sativi folium, we have observed a specific structure of the mesophyll, with four layers of palisade and a spongy parenchyma (Figure 2a). However, other authors, Miyake and co-workers have observed only one or two layers of palisade [25]. The midrib presents in the upper-third only one collateral bundle surrounded by colenchimatic pericycle; in the lower-third, it has five opened collateral bundles. Secondary veins show bundles without colenchimatic pericycle. The parenchyma cells have cellulosic walls. On the lower epidermis, rare unicellular trichomes were observed (Figures $2 \mathrm{~b}$ and 2c).

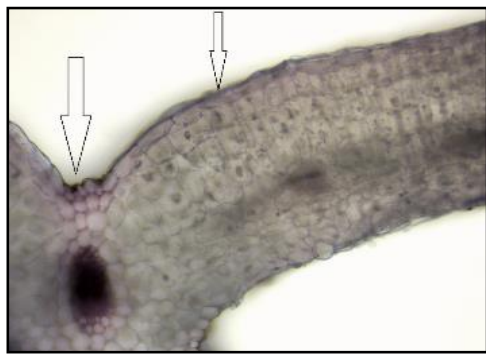

a)

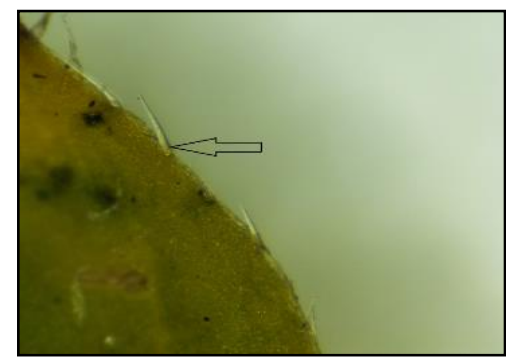

b)

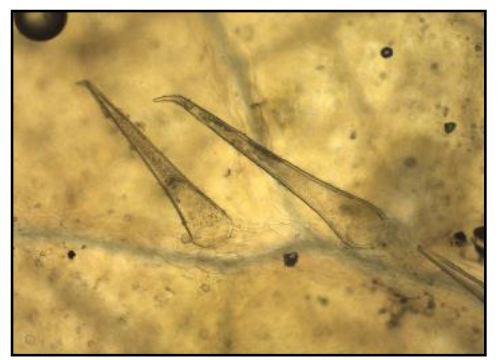

c)

Figure 2.

Anatomical elements for Raphani sativi folium: a) asymmetric heterogenous structure of the lamina, ob.10x; b) unicellular trichomes (digital microphotography); c) unicellular trichomes ob.10x

The extraction yield was $13.84 \%$ for $F E E$ and $26.05 \%$ for $R S E$. Hydroalcoholic dry extracts have the same organoleptic characteristics of the raw materials; FEE is green-brownish coloured, while $R S E$ is browngreenish coloured. Both extracts have a specific smell. The results of the quantitative determinations are found in Table I. RSE has a higher content of TPC and FL than FEE. PAC prevails in FEE when compared to $R S E$. Differences related to extracts obtaining procedures (different solvent, time of contact, raw material:solvent ratio) and raw material quality makes the comparison of our data with the ones from scientific literature difficult. The flavonoid content of FEE (36 mg/g hyperoside or equivalent to $23.48 \mathrm{mg}$ quercetin $/ \mathrm{g}$ extract) is lower than the results found by Preeti and co-workers (43 $\mathrm{mg}$ quercetin/g extract) [32]. In oposition, $R S E$ has a higher content of flavonoids

compared to other authors results (67.30 $\mathrm{mg}$ hyperoside/g extract equivalent to $43.64 \mathrm{mg}$ quercetin/g extract $v s$. $10.423 \mathrm{mg}$ quercetin/g extract found by Goyeneche and co-workers) [17]. Data related to PCA total content weren't found in other reports, therefore a comparison was not possible. The TPC content for RSE falls within the limit found by other authors $(21.4175 \mathrm{~g} \%$ TPC expressed as tannic acid is equivalent to 2.1408 g\% TPC expressed as gallic acid $v s .0 .659 \mathrm{mg} \%$ TPC expressed as gallic acid, Goyeneche and co-workers, and $9.80 \mathrm{~g} \%$ TPC expressed as gallic acid, Eugenio and co-workers) $[13,17]$. In the case of FEE, the TPC content is lower than other findings (13.32 g\% TPC expressed as tannic acid equivalent to $2.27 \mathrm{~g} \% \mathrm{TPC}$ expressed as catechin $v s .5 .88 \mathrm{~g} \%$ TPC expressed as catechin) [41].

Table I

Results of the spectrophotometric determinations

\begin{tabular}{|c|c|c|c|}
\hline Dry extract & g\% FL & g\% PCA & g\% TPC \\
\hline $\boldsymbol{F E} \boldsymbol{E}$ & $3.6140 \pm 0.4000$ & $5.9507 \pm 0.3800$ & $13.3299 \pm 0.1583$ \\
\hline $\boldsymbol{R S} \boldsymbol{E}$ & $6.7300 \pm 0.6600$ & $3.1263 \pm 0.1500$ & $21.4175 \pm 0.9454$ \\
\hline
\end{tabular}

FEE - Fici elastici extractum, RSE - Raphani sativi extractum, $\mathrm{PCA}=$ phenolcarboxylic acids; $\mathrm{FL}=$ flavonoids; $\mathrm{TPC}=$ total phenolic content. Results are mean \pm SD (standard deviation) $(\mathrm{n}=3)$

The HPLC analysis of RSE confirmed the presence of apigenin-7-glucoside, but not of rutin. Both compounds are mentioned by scientific data $[1,31]$. Also, phenolcarboxylic derivatives like ferulic acid and caffeic acid were not identified, despite other research data [31].

The chromatographic analysis of FEE indicated a main compound (unidentified due to lack of standard) with two absorption bands in the UV/visible region, 
FARMACIA, 2019, Vol. 67, 5

similar to flavans derivatives compounds: $284 \mathrm{~nm}$ (main band; Band $\mathrm{I}$ in the 250 - $285 \mathrm{~nm}$ range representing A ring absorption) and $320 \mathrm{~nm}$ (Band II in the $320-385 \mathrm{~nm}$ range representing the $\mathrm{B}$ ring absorption) [34].

We suppose that this compound belongs to the flavonoidic group, namely tannins due to several reasons: i) UV maxima at $284 \mathrm{~nm}$ falls within the UV features of condensed tannins (280 - $300 \mathrm{~nm})$ and is very similar to other catechin derivatives from other Ficus sp. (270 nm - gallocatechingalat; $275 \mathrm{~nm}$ - epigallocatechin; $250 \mathrm{~nm}$ - catechin, 280 nm - epi-afzelechin) [23,27]; ii) a tannin compound from Manihot esculenta is characterised by UV maxima at $320 \mathrm{~nm}$ (and UV maxima at $280 \mathrm{~nm}$ ) [23]; iii) a lack of other UV maxima describing other flavans derivatives, like $520 \mathrm{~nm}$ - for coloured

substances (anthocyanidins) or $360 \mathrm{~nm}$ - for flavonol group [3]; iv) tannins presence in Fici elastici folium [32].

Our results regarding in vitro antioxidant activity showed that FEE had the best antioxidant activity independent of the method used, since lower values of $\mathrm{EC}_{50}(\mathrm{mg} / \mathrm{mL})$ were observed compared to $R S E$ (Table II). The scavenger activity of FEE against DPPH free radical was established for $0.8-10 \mathrm{mg}$ extract $/ \mathrm{mL}$, and the highest inhibition percent $65 \%$ was found at $10 \mathrm{mg} / \mathrm{mL}$ (Figure 3a). The antioxidant activity is lower compared to a methanolic dry extract $\left(\mathrm{IC}_{50}=6.4166 \pm 0.3329 \mathrm{mg} / \mathrm{mL}\right.$ vs. $27.17 \mu \mathrm{g} / \mathrm{mL}$ [32]. RSE scavenges DPPH free radical at a higher domain of concentration $(2.5-15 \mathrm{mg} / \mathrm{mL})$, the highest inhibition percent $85 \%$ was found at $15 \mathrm{mg} / \mathrm{mL}$ (Figure 4a).

Table II

$\mathrm{EC}_{50}(\mathrm{mg} / \mathrm{mL})$ values for the analysed dry extracts

\begin{tabular}{|c|c|c|c|}
\hline \multirow{2}{*}{ Dry extract } & \multicolumn{3}{|c|}{ ANTIOXIDANT ASSAY - EC } \\
\cline { 2 - 4 } & DPPH & (mg/mL) \\
\hline $\boldsymbol{F E} E$ & $6.4166 \pm 0.3329$ & $0.0768 \pm 0.0020$ & $0.4027 \pm 0.0016$ \\
\hline $\boldsymbol{R S E}$ & $7.5100 \pm 0.1414$ & $0.2611 \pm 0.1893$ & $1.3935 \pm 0.0111$ \\
\hline
\end{tabular}

FEE - Fici elastici extractum, RSE - Raphani sativi extractum. Results are mean \pm SD (standard deviation) $(\mathrm{n}=3)$

TPC content is not well-corelated with the scavenger activity towards DPPH free radical, probably because other (unquantified, but mentioned) compounds like, scopoletin [31], polysaccharides [31] or sterols [32] may act as antioxidants against DPPH [4, 22, 44]. Another explanation is that other compounds like ascorbic acid, amine (tyrosine), sulphur compounds (for Raphani sativi folium) or carboxylic acids (acetic and formic acids) may interfere with Folin-Ciocâlteu reagent overestimating the TPC content of the extracts [5].

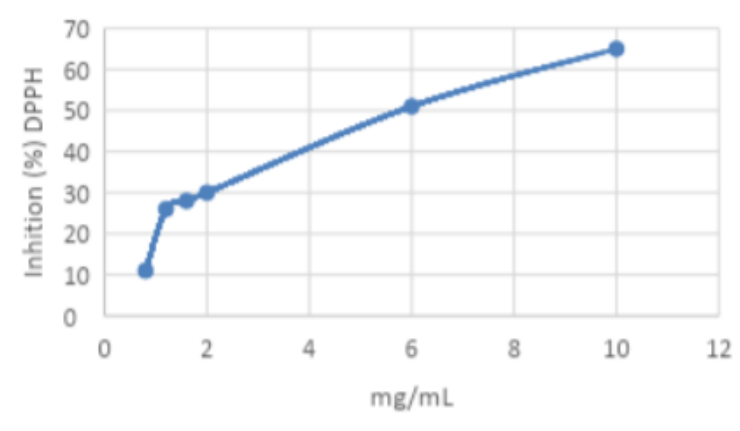

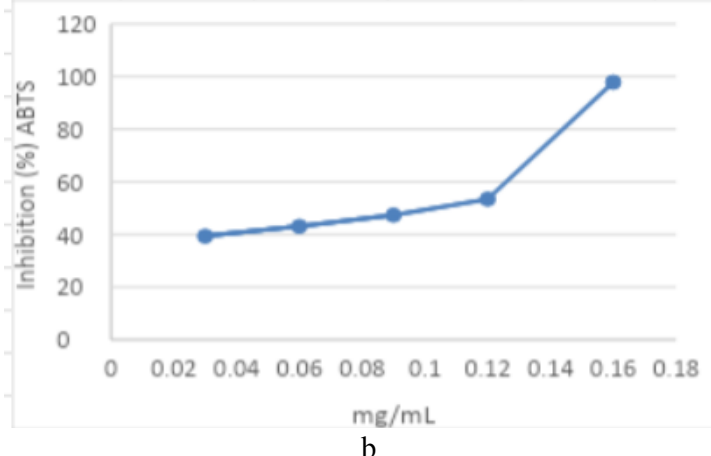

$\mathrm{b}$

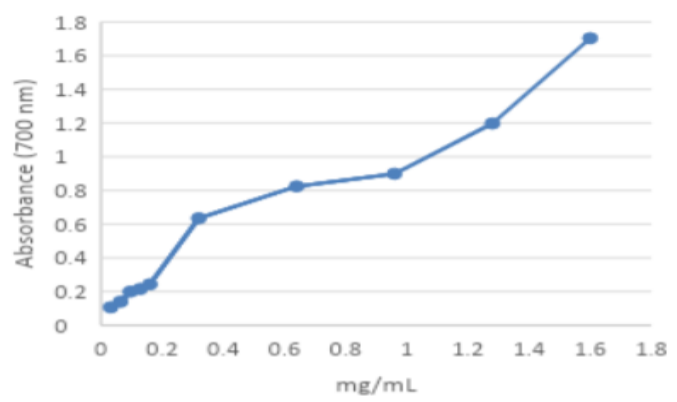

$\mathrm{c}$

Figure 3.

Antioxidant capacity of FEE: a - DPPH assay, b - ABTS assay, c - ferric reducing power 
As shown in Figure $3 \mathrm{~b}$, the scavenger activity towards $\mathrm{ABTS}^{\circ+}$ free radical for $F E E$, at the highest concentration $(0.16 \mathrm{mg} / \mathrm{mL})$ was $97.87 \%$. Regarding ferric reducing power, the absorbance values varies between 0.1068 (at $0.032 \mathrm{mg} / \mathrm{mL}$ ) and 1.7034 (at $1.6 \mathrm{mg} / \mathrm{mL}$ ) (Figure $3 \mathrm{c}$ ). The comparison of our results with other authors work was difficult, since most scientific studies refers to the antioxidant capacity of other Fici sp. folium (Ficus glomerata Roxb., Ficus carica Linn. or Ficus benjamina L.) $[11,12,18]$. However, we assume that phenolic compounds

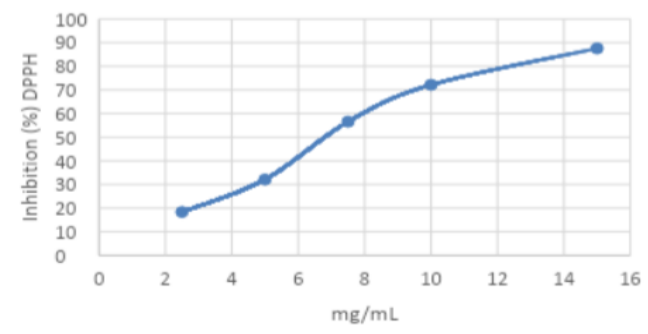

a

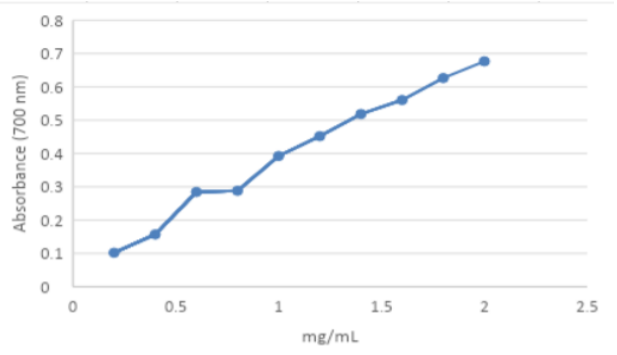

Figure 4.

Antioxidant capacity of RSE: a - DPPH assay, b - ABTS assay, c - ferric reducing power
According to other authors, Raphani sativi folium have also shown antioxidant activity, but the comparison with our results was hard due to different extraction solvents and methods [17, 21]. According to our results flavones (apigenin-7-glucoside) and phenolcarboxylic acids are responsible for the antioxidant activity. Moreover, the scientific literature foresees the presence of other phenols (caffeic acid, $p$-coumaric acid, caffeoylmalic acid, epicatechin, sinapic acid, tyrosol, kaempferitrin) [17], which are well known as metal chelators, reducing agents, hydrogen donors, singlet oxygen quenchers and superoxide radical scavengers. Additionally, they are also involved in activation of humans antioxidant defence system, since they enhance superoxide dismutase, catalase and glutathione peroxidase activities [24]. Over and besides, minerals (zinc, manganese, magnesium - which are reported for radish leaves) [17] might also be involved in the overall antioxidant activity.

\section{Conclusions}

The phytochemical study reveals a diverse chemical composition and high polyphenolic content for both extracts, especially in the case of Raphani sativi (determined by us using both spectrophotometric and chromatographic methods) together with triterpenes, sterols or minerals (mentioned by scientific literature) might be responsible for the overall antioxidant capacity [37].

$R S E$ also scavenged $\mathrm{ABTS}^{\cdot+}$ free radical in a dosedependent manner (Figure $4 b$ ). The dry extract displayed scavenging activity with values ranging from $43.12 \%$ (at $0.2 \mathrm{mg} / \mathrm{mL}$ ) to $82.41 \%$ (at $1 \mathrm{mg} / \mathrm{mL}$ ). Regarding its ferric reducing power, at the highest concentration the absorbance was 0.6766 (Figure 4c).

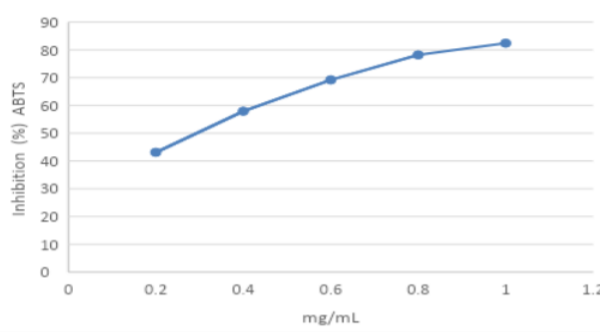

$\mathrm{b}$ extractum. The scavenger activity against free radicals was proved for both extracts, although Fici elastici extractum exhibited the highest antioxidant potential when compared to Raphani sativi extractum.

\section{References}

1. Agarwal K, Ranjana V, Radical scavenging ability and biochemical screening of a common Asian vegetable Raphanus sativus L. Int J Pharm Sci Rev Res., 2014; 27(1): 127-134.

2. Al Hilfi ZAF, Seremet OC, Morosan E, Stefanescu E, Ancuceanu RV, Stoicescu CD, Dinu M, Negres S, The antidiabetic potential of the hydroethanolic dry extracts obtained from the leaves of Raphanus sativus and Ficus elastica. Proceedings of The Romanian National Congress of Pharmacy $-17^{\text {th }}$ Edition, " $21^{\text {st }}$ Century Pharmacy - Between Intelligent Specialization and Social Responsibility" Filodiritto International Editore, Italy, 2018; 15-19.

3. Aleixandre-Tudo JL, du Toit W, The Role of UVVisible spectroscopy for phenolic compounds quantification in winemaking, in Frontiers and New Trends in the Science of Fermented Food and Beverages, Intech Open Limited, 2018; 6.

4. Ayaz M, Junaid M, Ullah F, Subhan F, Sadiq A, Ali G, Ovais M, Shahid M., Ahmad A, Wadood A, 
FARMACIA, 2019, Vol. 67, 5

El-Shazly M, Ahmad N, Ahmad S, Anti-Alzheimer's studies on $\beta$-sitosterol isolated from Polygonum hydropiper L. Front Pharmacol., 2017; 8: 1-16.

5. Bastola K, GuragainY, Vamsi B, Vadlani V, Evaluation of standards and interfering compounds in the determination of phenolics by Folin-Ciocalteu assay method for effective bioprocessing of biomass. $\mathrm{Am}$ J Anal Chem., 2017; 8(06): 416-431.

6. Beck $\mathrm{CB}$, An introduction to plant structure and development: Plant anatomy for the twenty-first century. Cambridge University Press, Cambridge, 2010, $2^{\text {nd }}$ ed., 270.

7. Bercu R, Popoviciu DR, Anatomical study of Ficus carica L. leaf. Annals of RSCB, 2014; XIX(1): 33-36.

8. Brand-Williams W, Cuvelier ME, Berset C, Use of a free radical method to evaluate antioxidant activity. Food Science and Technology, 1995; 28(1): 25-30.

9. Costea T, Lupu AR, Vlase L, Nencu I, Gîrd CE, Phenolic content and antioxidant activity of a raspberry leaf dry extract. Romanian Biotech Let., 2016; 21(2): 11345-11356.

10. Dinu M, Ancuceanu R, Hovaneț M, Anghel AI, Crețu O, Rebegea OC, Olaru OT, Pharmaceutical botany, theoretical and practical bases. Cytology, histology, organography. $3^{\text {rd }}$ ed., University Publishing House, Bucharest, 2013: 77-89, 161-201. (available in Romanian)

11. Eshwarappa RSB, Iyer S, Subaramaihha SR, Richard SA, Dhananjaya BL, Antioxidant activities of Ficus glomerata (moraceae) leaf gall extracts. Pharmacog Res., 2015; 7(1): 114-120.

12. Eteraf-Oskouei T, Allahyari S, Delazar A, Pashaii M, Gan SH, Najafi M, Methanolic extract of Ficus carica Linn. leaves exerts antiangiogenesis effects based on the rat air pouch model of inflammation. Evid Based Complement Alt Med., 2015; 2015: 1-10.

13. Eugenio MHA, Alvarenga Pereira RGF, César de Abreu W, Cardoso de Angelis Pereir M, Phenolic compounds and antioxidant activity of tuberous root leaves, Int J Food Propert., 2017; 20 (12): 2966-2973.

14. Gîrd CE, Costea T, Nencu I, Duţu LE, Popescu ML, Balaci TD, Comparative pharmacognostic analysis of Romanian Ocimum basilicum L. and $O$. basiclicum var. purpurascens Benth. aerial parts. Farmacia, 2015; 63(6): 840-844.

15. Gîrd CE, Nencu I, Popescu ML, Costea T, Duţu LE, Balaci TD, Olaru OT, Chemical, antioxidant and toxicity evaluation of rosemary leaves and its dry extract. Farmacia, 2017; 65 (6): 978-983.

16. Gorwadiya SRM, Vachhani KV, Desai TR, Pandya DJ, Pharmacognostic study and establishment of quality parameters of leaves of Ficus racemosa Linn. Pharmacog J., 2010; 2(15): 15-20.

17. Goyeneche R, Roura S, Ponce A, Vega-Gálvez A, Quispe-Fuentes I, Uribe E, Di Scala K, Chemical characterization and antioxidant capacity of red radish (Raphanus sativus L.) leaves and roots. J Funct Foods, 2015; 16: 256-264.

18. Imran M, Rasool N, Rizwan K, Zubair M, Riaz M, Zia-Ul-Haq M, Jaafar HZ, Chemical composition and biological studies of Ficus benjamina. Chem Central J., 2014; 8(1): 1-10.
19. Kesarwani K, Gupta R, Mukerjee A, Bioavailability enhancers of herbal origin: an overview. Asian Pac J Trop Biomed., 2013; 3(4): 253-266.

20. Kiem PV, Minh CV, Nhiem NX, Tai BH, Quang TH, Anh HL, Cuong NX, Hai TN, Kim SH, Kim JK, Jang HD, Chemical constituents of the Ficus elastica leaves and their antioxidant activities. Bul Korean Chem Soc., 2012; 33(10): 3461-3464.

21. Luo X, Zhang H, Duan Y, Chen G, Protective effects of radish (Raphanus sativus L.) leaves extract against hydrogen peroxide-induced oxidative damage in human fetal lung fibroblast (MRC-5) cells. Biomed \& Pharmacother., 2018; 103: 406-414.

22. Malik A, Kushnoor A, Saini V, Singhal S, Kumar S, Yogesh Chand Yadav YC, In vitro antioxidant properties of scopoletin, J Chem Pharm Res., 2011; 3(3): 659665.

23. Marie-Magdeleine C, Udino L, Philibert L, Bocage $\mathrm{B}$, Archimede $\mathrm{H}$, In vitro effects of Cassava (Manihot esculenta) leaf extracts on four development stages of Haemonchus contortus. Vet Parasitol., 2010; 173(1): 85-92.

24. Martins N, Barros L, Ferreira IC, In vivo antioxidant activity of phenolic compounds: Facts and gaps. Trends in Food Science \& Technology, 2016; 48: $1-12$.

25. Miyake H, Matsumura H, Fujinuma Y, TotsukaT, Effects of low concentrations of ozone on the fine structure of radish leaves. New Phytologist., 1989; 111(2): 187-195.

26. Nencu I, Popescu LM, Istudor V, Costea T, Duţu LE, Gîrd CE, The selection of technological parameters in order to obtain an extract with important antioxidant activity from stinging nettle leaves. Farmacia, 2017; 65(2): 295-300.

27. Omar MH, Mullen W, Crozier A, Identification of proanthocyanidin dimers and trimers, flavone cglycosides, and antioxidants in Ficus deltoidea, a Malaysian herbal tea maizatul. J Agric Food Chem., 2011; 59(4): 1363-1369.

28. Oyaizu M, Studies on products of browning reactions: antioxidative activities of browning reaction prepared from glucosamine. Jpn J Nutr., 1986; 44: 307-315.

29. Park HJ, Song M. Leaves of Raphanus sativus L. shows anti-inflammatory activity in LPS-stimulated macrophages via suppression of COX-2 and iNOS expression. Preventive Nutrition and Food Science, 2017; 22(1): 50-55.

30. Peng Y, Bishop KS, Quek SY, Extraction optimization, antioxidant capacity and phenolic profiling of extracts from flesh, peel and whole fruit of New Zealand grown Feijoa cultivars. Antioxidants, 2019; 8(5): 1-17.

31. Pérez Gutiérrez RM, Perez RL, Raphanus sativus (Radish): Their chemistry and biology. Sci World J., 2004; 4: 811-837.

32. Preeti AJ, Gaurav K, Loganathan K, Kokati VB, Phytochemical composition and antioxidant activity of Ficus elastica Roxb. (Moraceae) leaves. Res $J$ Pharm Tech., 2015; 8(3): 259-264.

33. Re R, Pellegrini N, Proteggente A, Pannala A, Yang M, Rice-Evans C, Antioxidant activity applying improved ABTS radical cation decolorization assay. Free Rad Bio Med., 1999; 26 (9/10): 1231-1237. 
34. Rice-Evans CA, Miller NJ, Paganga G, Structureantioxidant activity relationships of flavonoids and phenolic acids. Free Rad Biol Med., 1996; 20(7): 933-956.

35. Shakir HM, Baji SH, Anatomical study of some characters in certain species of genus Ficus L. growing in Iraq. J Biol Agric Healthcare, 2016; 6(12): 98-105.

36. Singleton VL, Rosi JA, Colorimetry of total polyphenol with phosphomolybdic - phosphotungstic acid reagents. Am J Enol Vitic., 1965; 37: 144-158.

37. Sirisha N, Sreenivasulu M, Sangeeta K, Chetty CM, Antioxidant properties of Ficus species - A review. Int J PharmTech Res., 2010; 2(4): 2174-2182.

38. Sonibare MA, Jayeola AA, Egunyomi A, Comparative leaf anatomy of Ficus Linn. species (Moraceae) from Nigeria. J App Sci., 2006; 6(15): 3016-3025.

39. Tahmasebi-Boldaji R, Hatamipour MS, Khanahmadi M, Sadeh P, Najafipour I, Ultrasound-assisted packedbed extraction of hypericin from Hypericum perforatum L. and optimization by response surface methodology. Ultrason Sonochem., 2019; 57: 89-97.

40. Teinkela JE, Noundou XS, Nguemfo EL, Meyer F, Wintjens R, Isaacs M, Mpondo AE, Hoppe HC, Krause RW, Azebaze AG, Biological activities of plant extracts from Ficus elastica and Selaginella vogelli: An antimalarial, antitrypanosomal and cytotoxity evaluation. Saudi J Biolog Sci., 2018; 25(1): 117-122

41. Teixeira DM, Canelas VC, Martins do Canto A, Teixeira JMG, Barrocas Dias C, HPLC-DAD quantification of phenolic compounds contributing to the antioxidant activity of Maclura pomifera, Ficus carica and Ficus elastica extracts. Anal Let., 2009; 42: 2986-3003.

42. Y1lmaz FM, Karaaslan M, Vardin H, Optimization of extraction parameters on the isolation of phenolic compounds from sour cherry (Prunus cerasus L.) pomace. J Food Sci Technol., 2015; 52(5): 2851-2859.

43. Zhang H, Birch J, Xie C, Yang H, El-Din Bekhit A, Optimization of ultrasound assisted extraction method for phytochemical compounds and in-vitro antioxidant activity of New Zealand and China Asparagus cultivars (officinalis L.) roots extracts. Food Chem., 2019; 294: 276-284.

44. Zhang Z, Jin J, Shi L, Antioxidant activity of the derivatives of polysaccharide extracted from a Chinese medical herb (Ramulus mori). Food Sci Tech Res., 2008; 14(2): 160-168. 